IZA DP No. 9826

The Effect of University Attended on Graduates' Labour Market Prospects: A Field Study of Great Britain

Nick Drydakis

March 2016 


\title{
The Effect of University Attended on Graduates' Labour Market Prospects: A Field Study of Great Britain
}

\author{
Nick Drydakis \\ Anglia Ruskin University \\ and IZA
}

Discussion Paper No. 9826

March 2016

\author{
IZA \\ P.O. Box 7240 \\ 53072 Bonn \\ Germany \\ Phone: +49-228-3894-0 \\ Fax: +49-228-3894-180 \\ E-mail: iza@iza.org
}

Any opinions expressed here are those of the author(s) and not those of IZA. Research published in this series may include views on policy, but the institute itself takes no institutional policy positions. The IZA research network is committed to the IZA Guiding Principles of Research Integrity.

The Institute for the Study of Labor (IZA) in Bonn is a local and virtual international research center and a place of communication between science, politics and business. IZA is an independent nonprofit organization supported by Deutsche Post Foundation. The center is associated with the University of Bonn and offers a stimulating research environment through its international network, workshops and conferences, data service, project support, research visits and doctoral program. IZA engages in (i) original and internationally competitive research in all fields of labor economics, (ii) development of policy concepts, and (iii) dissemination of research results and concepts to the interested public.

IZA Discussion Papers often represent preliminary work and are circulated to encourage discussion. Citation of such a paper should account for its provisional character. A revised version may be available directly from the author. 


\section{ABSTRACT \\ The Effect of University Attended on Graduates' Labour Market Prospects: A Field Study of Great Britain*}

Utilizing data for comparable BSc graduates in economics who have studied in different universities that had set the same entry standards, we compare job seekers' employment prospects when they search by themselves for jobs by submitting CVs to the same firms. The outcomes suggest that graduates who studied in universities that are ranked in better positions, based on the UK league tables, gain more invitations to interviews (access to vacancies) and higher entry-level annual salaries than those who studied in universities that are ranked in lower positions. To clarify the assigned pattern, we utilized further qualitative indicators, and we estimated that both membership of a scholarly group of universities and universities' research intensity can positively affect their graduates' invitations to interviews and entry-level annual salaries. Interestingly, by assessing the influence of degree grades, the study suggested also that applicants' degree grades can moderate the relation between university attended and employment prospects.

JEL Classification: $\quad 123,126$

Keywords: $\quad$ university, ranking, reputation, access to vacancies, entry-level annual salaries

Corresponding author:

Nick Drydakis

Lord Ashcroft International Business School

Anglia Ruskin University

East Road

Cambridge, CB1 1PT

United Kingdom

E-mail: nick.drydakis@anglia.ac.uk

\footnotetext{
* The project could not have happened without outstanding help, assistance and comments kindly provided by several UK universities (anonymously). I appreciate the study's participants and Anglia Ruskin University students for their able and cheerful assistance with data collection.
} 


\section{Introduction}

A persistent question in the empirical literature is whether the university attended and its corresponding quality indicators affects graduates' prospects in the labour market. Studies emphasize that convincingly estimating the economic returns based on the university attended requires overcoming the biases arising from the fact that attendance at a betterquality university is likely to be correlated with unobserved characteristics that will themselves affect future earnings (Hoekstra, 2009; Broecke, 2012). Unobserved characteristics in relation to students' motivation, commitment, ability, skills, and personality characteristics, may be rewarded in the labour market (Brewer et al., 1999; Hoekstra, 2009; Dale and Krueger, 2002). That is, more able students studying in more reputable and selective universities may have the desirable characteristics that firms require. In addition, students' socioeconomic backgrounds, such as family characteristics, parental support and networks, could affect their labour market outcomes, and thus some students may have greater employability and salary capacity regardless of the university attended (Brewer et al., 1999; Hoekstra, 2009; Dale and Krueger, 2002). The literature concludes that, based on these difficult-to-control unobserved characteristics, firm conclusions on the relation between university attended and labour prospects cannot be drawn.

Ideally, in order to minimize the omitted-variable bias problem and evaluate the effect of university attended on graduates' employment prospects, research should utilize two identical graduates with the same pre-university characteristics, who have studied in different universities that set the same entry standards, and it should compare their employment outcomes when they search by themselves for a job. In the current study, we have attempted to use a comparable method. Through a field experiment, we evaluate whether comparable third-year university students who have obtained a BSc in economics from different UK universities which have the same entry criteria, thus being the same selective group, face different labour market prospects when applying to the same firms.

This study contributes to the literature in three ways. First, this study is one of the first field studies to collaborate with real university students to estimate the effect of university attended on their invitations for interviews (i.e. access to vacancies) and entry-level salaries, minimizing unobserved heterogeneities that would themselves affect subsequent outcomes in the labour market. Based on the data-gathering design, we can observe as much information as the firms themselves. Working with students who have studied in universities with the same entry standards and acquired the same degree grades, we attempted to solve the problem of firms seeing more information than researchers by looking at an outcome that is 
determined before firms see any unobservable characteristics. Due to the study's design, job search-related support networks and family characteristics cannot affect applicants' employment prospects by default. This feature enables the research to overcome core biases arising from the fact that attendance at a selective university is likely to be correlated with unobserved characteristics that will themselves affect labour market prospects (Berkowitz and Hoekstra, 2011; Broecke, 2012). Secondly, having minimized the effect of the aforementioned core unobserved heterogeneities, we offer clear evaluations of how universities' quality differences, such as membership of a scholarly group (Russell Group membership ${ }^{1}$ ), research intensity (Research Assessment Exercise), and students' satisfaction (National Student Survey), affect their graduates' invitations to interviews and entry-level annual salaries. Thirdly, in this study we further analysed students' degree grades, in order to examine whether degree grades can moderate the effect of university attended in relation to students' invitations to interviews and entry-level annual salaries. Having minimized core heterogeneities, the design of this study will enable us to offer straightforward evaluations by capturing patterns in the field on the relation between university attended and students' labour market prospects. Thus, this study aims to provide evaluations of three main questions:

(1) Can the university attended affect graduates' invitations to interviews and entry-level annual salaries?

(2) Can universities' membership of a scholarly group (Russell Group), research intensity (RAE score), and students' satisfaction (NSS score) affect graduates' invitations to interviews and entry-level annual salaries?

(3) Can university grades obtained moderate the relation between universities attended and graduates' invitations to interviews and entry-level annual salaries?

In what follows, the next section provides a review of the literature on the effect of higher education quality on graduates' earnings. Section 3 describes the methodology in detail. Section 4 presents descriptive statistics, and Section 5 presents the results followed by a discussion.

${ }^{1}$ In Appendix I, we provide information regarding UK university entry standards, Russell Group membership, the Research Assessment Exercise and the National Student Survey. 


\section{Literature review}

All studies in the UK, and the majority of those in the US, suggest that a better-quality university positively affects its graduates' earnings. In the UK, Chevalier and Conlon (2003) estimated that graduates from better-quality universities gain an earning premium of approximately 4 percentage points. To measure universities' quality the authors utilized membership of a scholarly group of universities (Russell Group). Also, Hussain et al. (2009) found that one standard deviation in university quality is associated with an earning premium of the order of 6 percentage points. Several quality indicators were utilized, such as university entry standards, research intensity and faculty-student ratio. Moreover, Broecke (2012) estimated that a one standard deviation improvement in high school leaver university applications increases earnings by 7 percentage points. In addition, Drydakis (2015) found that university entry standards positively affect graduates' entry level annual salaries (between 5.3 and 16.4 percentage points).

In the US, Black and Smith (2004) found that earnings premiums are approximately 8 percentage points for graduates attending a better-quality university. The authors used university entry score indicators, fee differentials and faculty salary to measure quality. Similarly, Hoekstra (2009), using entry score as a quality indicator, estimated that graduates from better-quality universities receive 20 percentage points higher earnings. Also, Black and Smith (2006) estimated that university quality, as measured by entry standards, mean faculty salaries and faculty-student ratio, affects graduate earnings by 4 percentage points. Alternatively, in the US, two studies suggest that better-quality universities do not result in higher earnings (Dale and Krueger, 2002; 2014). Exemptions exist for black and Hispanic students, and for students who come from less well-educated families (Dale and Krueger, 2014).

In the examined literature, the reward for higher education in a reputable university is envisioned as the combined effect of human capital accumulation and of being identified as a skilled individual (Dobbs et al., 2008; Kjelland, 2008). Higher-ranked universities might attract better-qualified students in terms of academic ability and motivation when the admission system is selective (Hoekstra, 2009). Also, it might be the case that higher-ranked universities provide better education because of better resources, infrastructures and academic staff, and expand students' already superior abilities upon entry (Hartog et al., 2010; Dobbs et al., 2008; Black and Smith, 2004). Higher-ranked universities are characterized by excellent research-oriented teaching that enhances students' abilities in problem-solving, whereas those having strong links with industries enable students to build 
their portfolio on experiences from the business world. Thus, it is reasonable for employers to hire graduates on the basis of the human capital skills acquired in a university setting, which will consequently contribute to their productivity (Dobbs et al., 2008; Hartog et al., 2010).

In addition, several studies suggest that universities attended can affect not only graduates' human capital, but also the firms' screening process under conditions of uncertainty (Bedard, 2001; Brewer et al., 2002; Chevalier, 2004; Geiger, 2004; Hazelkorn, 2008; Kjelland, 2008). Students decide whether they will make a significant investment in terms of effort and time in order to enter a higher ranked university, and these investments should result in increased rewards from firms (Hanushek and Welch, 2006; Kjelland, 2008; Arcidiacono et al., 2010). Higher-ability students might find it easier to cope with the requirements of competitive universities, and the university system might simply provide employers with cheap sorting of students by demonstrating their productivity (Hartog et al., 2010). Productivity and the ability of a potential employee are not publicly observable, but the universities' quality is publicly available through league tables (Hanushek and Kimko, 2000; Bac, 2000; Chevalier and Conlon, 2003; Hanushek and Welch, 2006). Under conditions of uncertainty, universities attended and their corresponding quality indicators (ranked position in the League Tables, entry standards, research intensity, etc.) might highlight students' inherent human capital that they will bring to their new jobs, positively affecting graduates' labour market prospects. This might also be the case for reputable universities that have exclusive systems of mutual assistance, through which the employed alumni of a reputable university provide favourable treatment to its new graduates (Watts, 2003). That is, signalling this might be used to sort graduates according to their unobserved abilities (Altonji and Pierret, 2001). Thus, signalling and/or human capital arguments are the main channels through which better universities might positively affect graduates' labour market prospects, and in this study we adopt these frameworks in a process designed to evaluate potential patterns.

\section{Research design}

\subsection{Study's rationale and research outline}

The Higher Education Statistics Agency (HESA 2013) and the various league tables offer only raw data for graduates' employment, and thus we cannot evaluate whether graduates' employment is associated with the characteristics of their socio-economic background, pre-university grades, university attended, and its industrial characteristics. Also, we cannot determine whether graduates' employment is associated with their job search 
strategy, university social support networks, family characteristics and networks, and graduates' personality characteristics. Thus, the effect of university attended on graduates' employability cannot be quantified. Similarly, as we have already discovered based on the existing UK and US literature, due to the difficulty in controlling for the aforementioned core university and graduates' characteristics, it is difficult to provide precise evaluations of the relation between university attended and employment premiums. Consider also that all studies on the effect of university attended on graduates' prospects have focused on earnings rather than on graduates' invitations to interviews. Unfortunately, because of the absence of data on hiring, there is no relevant information regarding this important dimension that may affect recent graduates. However, whether a better quality university can affect graduates' invitations for interviews is of core importance for universities and students themselves. In terms of policy action, if improved access to vacancies are generated from better-quality universities, the economy could gain from policies that support the quality of all universities.

In this study, by utilizing a sender-type experiment which can control for students' pre-university differences, university degree grades, and minimize students' unobserved differences and network support in job searching, we are able to evaluate the effect of the university attended on graduates' employment prospects (Drydakis, 2015). Thus, this study addresses the literature's shortcomings in relation to core unobserved factors that might affect graduates' employment prospects, and fills a gap in relation to important outcomes: namely, graduates' invitations to interview and entry-level salaries.

In the sections that follow we will present in detail the adopted research strategy, and we will present the study's screening and matching criteria. Collaborating with real university students, the study consists of two experiments. In Experiment 1, a group of homogeneous third-year undergraduate students is created, studying in different universities applying for the same job openings. Applications are closely matched in terms of gender, age, ethnicity, pre-university qualifications, degree grades, experience, personality characteristics and other core features. Differential treatment in invitations to interview and entry-level annual salaries per university applicant are systematically measured. In Experiment 2, in order to investigate whether degree grades can moderate the relation between university attended and labour market prospects, a group of less homogeneous applicants in relation to university grade obtained is created, and, similarly to Experiment 1, employment prospects are systematically measured. In the descriptive statistics section, both experiments' stylized facts are presented; and then, through econometric modelling, estimated patterns are offered, having controlled 
for occupational heterogeneity, jobs and vacancies characteristics, and university quality characteristics.

\subsection{Methodology}

This research was administered as part of the Labour Market Study (LMS) conducted by Anglia Ruskin University in the UK. The research strategy was designed as follows. In the first stage, the research team matched economics departments in groups that have the same entry standards (for the sub-discipline: BSc in economics). The rationale was to reduce heterogeneity in students' pre-university human capital, and/or in terms of grouped universities based on their selectivity. Several matches were generated, with departments whose A-level grade requirements ranged from A+AA to CCB. In the second stage, the screening process focused on those matched groups in which all the universities included in the group were based in the same city. In doing so, we attempted to reduce regional heterogeneities. In the third stage, one group was randomly selected. Universities, as well as their geographical location, were anonymized, following the study's ethical standards.

The selected group consisted of three universities that offer a BSc in economics requiring the same entry standards ( $\mathrm{AAB}$, including $\mathrm{A}$ in mathematics), and are located in the same city. What is interesting and relevant to the scope of our study is that these universities are ranked in different positions based on the UK league tables. Each one of the three universities is ranked in a different group of ten. The university named Top 1 for the purpose of this study is listed in the first top ten (that is, between $1^{\text {st }}$ and $10^{\text {th }}$ ). The university named Top 2 for the purpose of this study is listed in the second top ten (that is, between $11^{\text {th }}$ and $20^{\text {th }}$ ). Lastly, the university named Top 3 for the purpose of this study is listed in the third top ten (that is, between $21^{\mathrm{st}}$ and $30^{\text {th }}$ ). All the league tables provide the same ten-ranking classification for these universities. In addition, the classification has not changed for the last three years. Importantly, the same ranking classification holds for the actual departments of economics. The Top 1 Department of Economics (Top 1 University) is listed in the first top ten, the Top 2 Department of Economics (Top 2 University) is listed in the second top ten, and the Top 3 Department of Economics (Top 3 University) is listed in the third top ten. A range of indexes is used by the league tables in order to rank universities, such as entry standards (A-levels), research intensity (RAE), and students' satisfaction (NSS). Although in this group of universities the entry standards are the same, variations in their research intensity and students' satisfaction have resulted in different ranking positions. For instance, the Top 1 University has a higher RAE score compared to the Top 2 and Top 3, but a lower 
NSS score compared to the Top 2 and Top 3. In addition, the Top 2 University has a higher RAE compared to Top 3, but a higher NSS compared to Top 1. Moreover, Top 3 University has a lower RAE compared to Top 2 University, but a higher NSS compared to Top 1 and Top 2. Finally, the Top 1 and Top 2 Universities are Russell Group members. The RAE and NSS comparisons hold for both the universities and the actual departments of economics. In Appendix II, we provide information of the characteristics of each university.

In November 2013, we made contact with the students' union and the employment service related to each of the three departments of economics, and we informed them of the aim of the study and requested their kind cooperation. The outcome was a statement that was posted in the universities' public areas, asking the 2014 spring semester BSc in economics applicants who were interested in seeking employment to voluntarily take part in our study, starting from April 2014. In the announcement we explained that for a period of three weeks, we would provide each participant with up to 40 random job openings per week in economics, for early-career economists. We informed participants that the scope was to record correspondences from firms. Importantly, we highlighted that the participants would be encouraged to apply only to those vacancies that were interesting to them. The students therefore had the option to make a choice and to follow their tastes.

Our announcement advised volunteers to use our affiliations and contact us. We explicitly suggested that volunteers sent us their resumes for feedback, and also to create a new university email account for the research purpose, to which it was desirable that the research team had access, in order to measure correspondence from firms. Instructions were provided, and in particular volunteers had to include in their resumes a list of information regarding their demographic characteristics, primary, secondary and university education. Finally, the announcement noted that volunteers would be eligible to receive a certification regarding their participation in the study at the end of a successful collaboration.

\subsection{Preparing the applications}

By the end of February 2014, 64 BSc in economics students (3-year programme) had made contact with the research team and forwarded their resumes. The descriptive statistics of the applicants' characteristics are offered in Table 1. For the study's purpose, all relevant characteristics of the applicants had to be identical, so that any systematic difference in treatment could most likely be attributed to the effects of the university attended. The applicants had to be matched on attributes such as gender, age, ethnicity, marital status, preuniversity qualifications, subject, personality characteristics and interests. According to the 
study's aim, based on the CVs' information, and in accordance with the screening and matching criteria, one student was selected from each university to participate in Experiment 1, and one student was selected to participate in Experiment 2. The aim of Experiment 1 required a group of homogeneous applicants to be created. On the other hand, the aim of the Experiment 2 called for a group of less homogeneous applicants. At the end of the CV screening process, a group of three students was created per experiment. In Experiment 1, Louise (Top 1 University), Ruth (Top 2 University) and Helen (Top 3 University) formed the group, and they agreed in writing to take part. In the Experiment 2, Lesley (Top 1 University), Diana (Top 2 University) and Rachel (Top 3 University) were also grouped, and gave their written consent to participate in our study.

\section{-Table 1-}

In Experiment 1, the applicants we worked with had the following characteristics: they were females, 21 years old, natives (white-British), unmarried, and they had attended state primary and secondary schools (non fee-paying). Moreover, they had the same preuniversity qualifications ( $\mathrm{A}$ in mathematics, $\mathrm{A}$ in economics and $\mathrm{B}$ in statistics at A-level) that fulfilled universities' entry standards, a similar subject (microeconomics, macroeconomics, econometrics), and equivalent software knowledge (Microsoft Office, Eviews, and SPSS). All applicants had achieved upper second-class honours (grade obtained $64 \%)$.

Each of the applicants gave their first and last UK name, a postal address, and a mobile telephone number. Moreover, they had similar personality characteristics, skills and hobbies. In addition, the contact details of two professors who would stand as referees in case of potential correspondence from firms were also provided in the application forms. Importantly, the resumes (i.e. cover letters and CVs) were organized in the same template and formatting. Working with human resources departments, internal pre-tests were conducted to ensure that none of the cover letters and CVs would elicit preferences. Appendix III summarizes the matched pairs for the first experiment.

In Experiment 2, the applicants had the same characteristics as in the first experiment, except in terms of their university grades. The applicant from the Top 1 University had a lower second (i.e., grade obtained 58\%), the applicant from the Top 2 University had an upper second (i.e., grade obtained 68\%), while the applicant from the Top 3 university had an upper first (i.e., grade obtained $75 \%$ ).

In both experiments, based on the qualitative information we have, these students had studied at their first choice of university, and they had not initially applied to the other two 
universities. Thus, in our sample, students studying in the Top 2 University had not been rejected from the Top 1 University. Similarly, students studying in the Top 3 University had not been rejected from the Top 1 and Top 2 Universities. In addition, none of the students had had an interview as a part of the selection process. These features suggest that we did not miss valuable information in relation to students' quality and motivation that might have played a critical role during the admission stage. Moreover, the fact that all the students in our sample had studied in state primary and secondary schools reduces further heterogeneities; for instance, attending a fee-paying primary and secondary school is likely to affect university selection and future employment prospects. Appendix IV summarizes the matched pairs for the second experiment, while Appendix $\mathbf{V}$ presents a sample of cover letter and $\mathrm{CV}$ data.

\subsection{Application process}

Students applied to entry-level job vacancies that were found through a random sample of job openings appearing in fifteen UK internet websites that advertised positions for graduate economists. These covered a wide spectrum of work environments; for instance, financial intermediation, consultancies, banking, the real estate and rental business, transport, storage and communication (see Appendix VI). In Experiment 1, the application submission process lasted for three weeks, between 5 and 25 of April 2014. During that period, on two days each week we provided random job openings to the applicants. Each participant received the same jobs openings $(n=120)$ as the other two. In Experiment 2, the application submission process took place between 5 and 25 May 2014, and we worked in the same way as in Experiment $1(\mathrm{n}=120)$. In each experiment we used different job openings. After the data gathering period, the evaluation showed that in Experiment 1 the applicants had applied to $74 \%$ of the job openings. In Experiment 2, the applicants applied to $78 \%$ of the job openings. Having access to their emails, we recorded the day and hour of the application as well as the firms' correspondence and the invitation for interview or rejection.

The evaluation showed that in Experiment 1, in $79 \%$ of cases all members of the pair had applied for the same jobs $(n=69)$. Similarly, in Experiment 2 , in $76 \%$ of cases $(n=71)$ all members of the pair had applied for the same jobs. In both experiments, we utilized those observations. By doing so, we conditioned for vacancy-fixed effects, minimizing firmunobserved heterogeneity. However, in the regression stage, if we consider the unrestricted sample we also obtain comparable patterns. 
In addition, for the research purpose, we also recorded the entry-level annual salary which was specified in each job opening, as well as some of the firms' characteristics, such as whether the firm is multinational and has a HR department. In Table 2, we provide the jobs' and the firms' descriptive statistics for those vacancies applied to by our applicants $(n=140)$. A large proportion of the jobs are in financial intermediation (21.6\%), real estate $(17.3 \%)$, and construction $(24.0 \%)$. The average entry-level annual salary that firms offer is $£ 31,110.2$. In addition, $22.1 \%$ of the firms offer fixed contracts. Furthermore, $31.4 \%$ of the firms are multinational, and $70.0 \%$ have human resources departments

[Table 2]

\section{Descriptive Statistics}

\subsection{Invitations to interviews}

In Table 3, Panel I, we present the aggregate results for invitations to interviews for Experiment 1, in which more homogeneous applications have been utilized. Although the three students had applied for the same vacancies, the applicant from the Top 1 University has the highest probability of receiving an invitation for an interview (59.4\%), followed by the applicant from the Top 2 University (31.8\%) and the applicant from the Top 3 University (21.7\%). There is an indication that, although the BSc in economics applicants have the same pre-university qualifications, were enrolled in universities demanding the same entry standards, have the same degree grade, gender, ethnic background, and work experience, they nevertheless face differences in their access to vacancies based on the university attended. The invitations to interviews difference is of the order of 27.5 percentage points between the applicants from the Top 1 and Top 2 Universities, 37.6 percentage points between the applicants from the Top 1 and Top 3 Universities, and 10.1 percentage points between the applicants from the Top 2 and Top 3 Universities. The assigned differences are statistically significant at least at the $5 \%$ level.

In Panel II, we present the invitations to interview results for Experiment 2, in which degree grades vary, where the applicant from the Top 1 University has the lowest degree grade, and the applicant from the Top 3 University has the highest degree grade. Similarly to Experiment 1, the applicant from the Top 1 University has the highest probability of receiving an invitation for an interview $(57.7 \%)$, followed by the applicant from the Top 2 University $(40.8 \%)$ and the applicant from the Top 3 University (32.2\%). Interestingly, although the invitations to interview differences between the Top 1 and Top 2 (by 16.9 percentage points), Top 1 and Top 3 (by 25.3 percentage points), and Top 2 and Top 3 (by 
8.4 percentage points) University applicants are statistically significant at least at the $10 \%$ level, the magnitude of the differences is lower compared to Experiment 1. Indeed, in Experiment 2 the invitations to interview probability for the Top 2 University applicant is higher compared to Experiment 1. The same pattern holds for the Top 3 University. However, for the Top 1 University applicant, the invitations to interview probabilities are lower in Experiment 2 compared to Experiment 1. It seems that the inter-relation between university attended and degree grade obtained affects firms' screening process in relation to invitations for interview.

\section{[Table 3]}

\subsection{Entry-Level Annual Salaries}

In Table 4, we present descriptive statistics regarding the entry-level annual salaries. In Panel I, observations for Experiment 1 are presented. It is observed that the Top 1 University applicant is invited for an interview by firms that offer $£ 32,351.2$ on average, whilst the Top 2 and Top 3 University applicants are invited for an interview by firms that offer $£ 29,145.4$ and $£ 27,926.6$ respectively. The Top 1 University applicant faces higherentry level salaries by 10.9 percentage points compared to the Top 2 University applicant. Similarly, the Top 1 University applicant faces higher entry level annual salaries by 13.6 percentage points compared to the Top 3 University applicant. The assigned differences are statistically significant at least at the 5\% level. It appears that the university attended affects not only the applicants' access to vacancies but also their entry salary prospects. This may suggest that firms which offer higher salaries tend to shortlist applicants for interview based on the university attended. However, the salary difference is insignificant between the applicants from the Top 2 and Top 3 Universities (4.1 percentage points).

In Panel II, we present Experiment 2's entry-level annual salaries per university applicant. As can be observed, the patterns assigned are qualitatively comparable to those of Experiment 1. The Top 1 University applicant is statistically significantly advantaged compared to Top 2 (by 6.8 percentage points) and Top 3 (9.2 percentage points) University applicants. However, the magnitude of the salary prospects difference is smaller in Experiment 2 than in Experiment 1. Indeed, as can be observed, in Experiment 1 the Top 1 University applicant who has obtained a higher degree grade faces higher salary prospects compared to her equivalent in Experiment 2, who has obtained a lower degree grade. Also, in Experiment 1, the Top 2 University applicant who has obtained a lower degree grade faces lower salary prospects compared to her equivalent in Experiment 2, who has obtained a 
higher degree grade. Comparable patterns hold for the Top 3 University applicants. Based on the design of this study and the characteristics of the samples, it seems that higher grades might moderate the relation between university attended and applicants' salary prospects.

[Table 4]

\section{Multivariate Analysis}

\subsection{Estimation framework}

The probability of an applicant receiving a job interview is estimated using a probit model (Drydakis, 2015):

$$
\begin{array}{lr}
\mathrm{Y}_{\mathrm{i}}^{*}=\beta_{1} \mathrm{Top}_{i}+\beta_{2} \mathrm{Top}_{i}+\beta_{3} \mathrm{Occ}_{i}+\beta_{4} \mathrm{Occ}_{i}+\beta_{5} \mathrm{Occ}_{i}+\beta_{6} \mathrm{Occ}_{i}+\beta_{7} \mathrm{Mult}_{i} \\
+\beta_{8} \mathrm{H} R_{i}+\beta_{9} \mathrm{Fix}_{i}+\beta_{10} \mathrm{On} A_{i}+\beta_{11} \operatorname{Sen} O_{i} & \\
+e_{i} & \text { Equation (1) }
\end{array}
$$

where all variables are binary dummies controlling for university attended, occupations, job and firm characteristics, and the study's effects. Y variable takes the value 1 if the applicant receives an invitation for interview and 0 otherwise. Top 2 variable equals 1 if the university is ranked second in this sample and 0 otherwise, and Top3 variable equals to 1 if the university is ranked third in this sample and 0 otherwise. The reference category (excluded category) is the Top 1 University.

Moreover, Occ1 variable takes the value 1 if the occupation is in financial intermediation, consultancy and banking and 0 otherwise, Occ2 variable equals 1 if the occupation is in real estate and renting and 0 otherwise, Occ3 variable equals 1 if the occupation is in health industry and social support and 0 otherwise, Occ4 variable takes the value 1 if the occupation is in transport, storage and communication and 0 otherwise. The reference category is jobs in manufacturing.

In addition, Mult variable equals 1 if the firm is multinational and 0 otherwise, HR variable takes the value 1 if the firm has a human resources department and 0 otherwise, FixC variable takes the value 1 if the vacancy is on a fixed-term contract and 0 otherwise. Furthermore, OnA variable equals 1 if the vacancy requires an online job application and 0 otherwise, and SenO variable equals 1 if the application from the Top 1 University applicant was sent first. Finally, e is the disturbance. 
In Table 5, Model I presents the estimate results for Experiment 1 invitations for interview. A statistically significant negative $\beta_{1}$ and/or $\beta_{2}$ coefficient would imply lower job interview probabilities as compared to the reference category. We present the average marginal effects, and in all estimations robust standards are presented, clustered at the occupation level. Similarly, in Model II we present the estimate results for Experiment 2, in which less homogeneous applications in relation to grade obtained have been utilized. To control for grade heterogeneity, Equation (1) is modified by adding one continuous variable called Grad, which measures applicants' grade obtained, which ranges between 58 and 75.

In Model III, we present the analysis of entry-level annual salaries. We use Equation (1), and the empirical strategy adopted in Model I, to estimate straightforward OLS log regressions on the applicants' entry-level annual salary prospects. Note that sample selection is not an issue. Salaries are observed from the beginning (the information is provided in the job advertisement), before an applicant receives the invitation for an interview or a job offer. Finally, in Model IV we present the estimate results for Experiment 2 by adding to Equation (1) the grade obtained information (Grad variable).

\subsection{Outcomes: Invitations to interviews}

In Table 5, we present the estimate results (Probit) for Experiment 1. In Model I, it is estimated that the applicant from the Top 2 University faces 27.9 percentage points lower chances of receiving an invitation for an interview than her comparable applicant from the Top 1 University. Also, it is estimated that the applicant from the Top 3 University faces 39.4 percentage points lower chances of receiving an invitation for an interview than the Top 1 applicant. Both estimations are statistically significant at the $1 \%$ level. Although the three applicants have the same pre-university qualifications and degree grade, the estimations suggest that the applicant from the Top 1 University faces more chances of receiving an invitation compared to the other two applicants. In addition, although the applicant from the Top 3 University has the same human capital, it seems to be less rewarded by the firms compared to the applicant from the Top 2 University. We conclude that the university attended can affect applicants' access to vacancies. Importantly, although both the Top 1 and Top 2 University applicants are studying in Russell Group universities, statistically significant variations in their access to vacancies exist. The outcomes of the current study suggest that between applicants from highly reputable universities, access to vacancies may vary.

\section{[Table 5]}


In Model II, we present the estimate results (Probit) for Experiment 2. It is observed that the applicants from the Top 2 and Top 3 Universities face lower chances of a job interview than the applicant from the Top 1 University, of the order of 17.3 percentage points and 28.5 percentage points respectively. The estimations are statistically significant at least at the 5\% level. Although the applicant from the Top 1 University has the same pre-university qualifications and a lower degree grade than her counterparts from the Top 2 and Top 3 Universities, she faces higher chances for an interview. Similarly, although the applicant from the Top 2 University has a lower degree grade than her counterpart from the Top 3 University, she faces higher chances of receiving an invitation for an interview.

Obviously, the magnitude of Experiment 2's coefficients is lower compared to those of Experiment 1. The moderating factor that affects the invitation to interviews rate might be the degree grades, which vary between the two experiments. Recall that in Experiment 2, the applicants from the Top 2 and Top 3 Universities have higher grades compared to those in Experiment 1. Based on the patterns assigned, it seems that in Experiment 2 the invitation to interview rate is affected by two effects the university attended, and degree grades. And, based on the assigned patterns, it seems that the former effect dominates the latter effect. As we observe in Model II, the university attended effect ranges between 17.3 and 28.5 percentage points, while the degree grades effect is of the order of 4.3 percentage points (i.e. a one standard deviation increase in degree grades increases students' invitation to interviews by 4.3 percentage points). Indeed, in Modell II it is observed that although applicants from the Top 1 and Top 2 Universities are studying in Russell Group universities, they continue to face differing access to vacancies, independently of the fact that the applicant from the Top 2 University has a higher degree grade than the applicant from the Top 1 University.

In Table 6 we present regression results (Probit) for the total sample of Experiments 1 and 2 (pooled estimations). The assigned patterns are in line with those presented in Table 5. As it is observed in Model I, the Top 2 and Top 3 University applicants face lower invitations to interviews than Top 1 University applicants, by 20.8 and 31.8 percentage points respectively. However, the interaction terms suggest that these applicants are in a better position in Experiment 2 than in Experiment 1. That is, the Top 2 and Top 3 University applicants are better off in Experiment 2 than in Experiment 1 by 6.5 and 9.4 percentage points respectively. Since the only difference between the two experiments is the degree grades obtained, it seems that grades can moderate the relation between university attended and invitations for interview. Indeed, as Model I also demonstrates, grades obtained positively affect invitations to interviews. 


\section{[Table 6]}

\subsection{Outcomes: Entry-level annual salaries}

In Table 5, we present the analysis of entry-level annual salaries (OLS). In Model III, the estimations suggest that the applicants from the Top 2 and Top 3 Universities face lower entry-level annual salary prospects by 11.3 percentage points and 15.3 percentage points than the applicant from the Top 1 University. The estimations are statistically significant at least at the 5\% level. Although both the Top 1 and Top 2 University students study in Russell Group universities, it is clear that the Top 1 University gives its student an entry-level annual salary privilege compared to those of the Top 2 and Top 3 Universities. Also, the Top 2 University gives its student an entry-level annual salary privilege compared to that of the Top 3 University.

In Model IV, we present the estimate results (OLS) for Experiment 2. It is observed that the applicants from the Top 2 and Top 3 Universities face lower salary prospects by 4.2 percentage points and 8.1 percentage points than the applicant from the Top 1 University. The former estimation is statistically insignificant, while the latter is statistically significant at the $5 \%$ level. As in the case of invitation to interview, the magnitude of the coefficients is lower compared to those of Experiment 1. The moderating factor that affects the entry-level annual salaries might be students' degree grades, which is the only characteristic that varies among university applicants between Experiments 1 and 2. It is observed that the university attended effect on entry-level annual salaries ranges between 4.2 and 8.1 percentage points, whereas the degree grades effect is of the order of 2.8 percentage points. We might conclude gain that the former effect dominates the latter effect.

These patterns are re-validated in Table 6, Model II, where pooled estimations (OLS) are presented (i.e. for both Experiments 1 and 2). We observe that the Top 2 and Top 3 University applicants face lower entry-level annual salary prospects than Top 1 University applicants by 8.1 and 9.5 percentage points respectively. However, these applicants are better off in Experiment 2 than in Experiment 1 by 2.7 and 2.9 percentage points respectively. And since the only difference between the two experiments is grades obtained, we suggest that they might moderate the relation between university attended and salary payoffs. In fact, it is observed that grades obtained can positively affect entry-level salaries by 1.8 percentage points. 


\subsection{Reputation indexes}

Although the patterns presented suggest that university attended can affect applicants' invitations to interviews and their entry-level annual salaries, we want to clarify which are the factors that may affect the Top 1 University applicant's privilege in comparison to the Top 2 and Top 3 University applicants; in addition, to examine the Top 2 University applicant's privilege in comparison to the Top 3 University applicant. As we have previously presented, although the three universities set the same entry standards, the Top 1 University is characterized as the most research-intensive university (RAE score), while the Top 3 University is characterized as the least research-intensive (RAE score). Also, the Top 1 and Top 2 Universities are Russell Group members, while the Top 3 University has the highest student satisfaction index (NSS score), and the Top 1 University has the lowest student satisfaction index (NSS score). Thus, we have three potential reputation indexes that may quantify the access to vacancies and entry-level annual salary differences between universities. However, in Table 5, for multicollinearity reasons we cannot control simultaneously for university attended (i.e. Top 2 and Top 3), Russell Group membership, research intensity (RAE score), and students' satisfaction (NSS score).

In Table 7, following the strategy of Black and Smith (2006), we can turn to the Generalized Method of Moments (GMM) estimator, in which we use one quality measure in the structural equation, for instance Russell Group membership, and the remaining two measures as instruments, for instance research intensity (RAE) and students' satisfaction (NSS). As it is observed in Specifications I-III, by adding quality indicators and utilizing GMM estimators, the main results continue to hold. The Top 1 University applicant is better off, in terms of higher invitations to interviews and entry-level annual salary prospects, than the Top 2 and Top 3 University applicants, and the Top 2 University applicant is better off than the Top 3 University applicant in terms of invitations to interviews and entry-level annual salaries. However, additional interesting patterns have been estimated that provide clarifications of the assigned outcomes.

In Model I, in Specification I, we present the estimate results (GMM-Probit) for Experiment 1 invitations to interview. Recall that in Experiment 1 the applicants are as homogeneous as possible. It is observed that a student studying in a Russell Group university faces 28.2 percentage points higher chances of receiving an invitation for an interview than her comparable applicant from a non-Russell Group university. This pattern might thus clarify why Top 1 and Top 2 University applicants who have studied in Russell Group universities are better off compared to the Top 3 University applicant, who has studied in a 
non-Russell Group university. Membership of a group of highly reputable universities might boost their graduates' employment prospects.

\section{[Table 7]}

In Model I, in Specification II, it is observed that universities' research intensity (RAE) affects students' invitations to interviews. That is, a one standard deviation increase in RAE score increases students' invitation to interviews by 2.1 percentage points. And since in this study the Top 1 University has the highest RAE score, while the Top 3 University has the lowest RAE score, we can suggest then that the Top 1 University applicant has an advantage in relation to invitations for interviews compared to the Top 2 and Top 3 University applicants, due to the Top 1 University's superiority in research intensity. Also, the estimated pattern might clarify why the Top 1 and Top 2 Universities' applicants face different invitation for interview prospects, although both universities belong to the Russell Group. The Top 1 University applicant might be privileged because her university is more active in research, which might highlight greater quality and reputation. Indeed, the interaction effect between the research intensity score (RAE) and the Top 2 University suggests that the effect of research intensity on applicants' invitations for interview is lower for the Top 2 University applicant than for the Top 1 University applicant. The same pattern holds for the interaction effect between the research intensity score (RAE) and the Top 3 University applicant. That is, research activity might entail a competitive advantage to the Top 1 University that affects its students' invitations to interviews. However, in Model I, Specification III, we observe that students' satisfaction (NSS score) does not affect their invitations to interviews in a statistically significant way.

In the same way, in Model II we present the estimate results (GMM-Probit) for Experiment 2. The patterns are qualitatively comparable to those of Experiment 1 . However, in all specifications the magnitude of the coefficients is lower compared to those of Experiment 1. Recall that in Experiment 2 the applicants have acquired heterogeneous degree grades. As the study's general pattern suggests, it seems that students' degree grades might moderate the relation between university attended and access to vacancies. That is, when the Top 3 University applicant has higher degree grades than the Top 1 and Top 2 University applicants, the Russell Group membership and research intensity premiums are lower compared to the case where all students have the same grades.

In Model III, we present the estimate results (GMM) for Experiment 1 entry-level annual salary. Those students having studied in Russell Group universities are invited for interview by firms that offer 11.3 percentage points higher entry-level annual salaries. Also, a 
one standard deviation increase in universities' research intensity (RAE) increases students' entry-level annual salaries by 2.9 percentage points. That is, the Top 1 and Top 2 University applicants face higher salary prospects because they have studied in Russell Group universities, compared to the Top 3 University applicant. Also, the Top 1 University applicant is better off than the Top 2 and Top 3 University applicants because her university is more research intensive, and this feature seems to positively affect the invitation to interviews rate from those firms that offer higher salaries. However, students' satisfaction (NSS) does not affect graduates' entry-level annual salaries.

Finally, in Model IV, we present the estimate results (GMM) for Experiment 2 entrylevel annual salary. The patterns are qualitatively comparable to those of Experiment 1; however, the magnitude of the coefficients is lower. As has been previously suggested, students' degree grades heterogeneity might act as a moderating factor for the effects of Russell Group membership and research intensity premiums on graduates' employment prospects.

\section{Discussion and conclusions}

In this study, we investigated whether university attended can affect graduates' invitations for interview and entry-level annual salaries, ensuring that bias problems caused by omitted variables, such as job seekers' motivation, personality characteristics and family/network support, cannot affect the relations under examination. By controlling several characteristics, such as gender, age, ethnicity, marital status, subject of degree, grade obtained, pre-professional experience, skills, and personal characteristics, we concluded that applicants who studied in universities that are ranked in better positions, based on the UK league tables, gain more invitations to interviews and higher entry-level annual salaries than those who studied in universities that are ranked in lower positions. To clarify the assigned pattern, we utilized qualitative indicators and we estimated that both membership of a scholarly group of universities (Russell Group membership) and universities' research intensity (RAE score) can positively affect their graduates' invitations to interviews and entry-level annual salaries. Also, by analysing degree grades, the study suggested that graduates' degree grades can moderate the relation between university attended and invitations to interview, as well as the relation between university attended and entry-level annual salaries.

The design of the current study allowed us to capture difficult-to-measure patterns, such as access to job vacancies and early annual salaries. We suggest that, even before 
meeting their applicants and evaluating for themselves their skills, motivation and personality characteristics, firms tend to favour those having acquired a degree from a university ranked in a better position. The results of this study are in line with previous UK and US studies that have found that university quality/reputation can affect graduates' earnings (Chevailer and Conlon, 2003; Hoekstra, 2009; Broecke, 2012). As we have discussed, the literature in this area suggests that education from reputable universities might increase an individual's human capital investment, and thus future productivity and earnings (Dobbs et al., 2008; Hartog et al., 2010). At the same time, given that academic excellence is correlated with specific universities, firms might screen applicants and reward them based on these criteria (Geiger, 2004; Hazelkorn, 2008; Kjelland, 2008).

In the international literature, most studies have examined graduates' subsequent earnings (i.e. three years after graduation). Importantly, however, our study gave us the opportunity to establish also that graduates from more reputable universities gain higher chances of receiving invitations for interviews, thus gaining improved access to occupations, and also that they are shortlisted for higher-earning jobs. The patterns of our study suggest that the universities attended might affect graduates' employment prospects from the preliminary stage of the hiring process (see, also Drydakis, 2015). Also, this study contributes to the domain of educational economics, because it provides a basis for future field studies in the area. Whether the current patterns are affected by greater university heterogeneity is an open question; also, whether industrial and occupational characteristics affect the outcomes requires further investigation.

In this study, since the outcome measures were taken before the applicants and the firms met in person, we were able to control for a great deal of information that firms may observe when meeting the applicants. Having done so, the outcomes are more informative and provide clearer patterns for the relationship between universities attended and labour market prospects, as compared to the cited studies, which fail to control for the potential impact of applicants' ability, skills, personality, and job search-related networks. Almost all of the previous researches did not consider the aforementioned core parameters, the omission of which from the econometric specification may have affected the interpretation of the results.

The patterns revealed by this study should be interesting for social planners, universities, and students. Currently, there is a general public interest regarding whether the university entered or the universities under consideration will affect graduates' chances of quick job placement, as well as future earnings. This study has come at a critical time for the 
higher education sector, considering the tripling of the UK tuition fees in 2012, which has affected students' choices, and caused universities to place tremendous emphasis on rankings in order to attract new students. Our study's outcomes have suggested that graduates' employment prospects are a function of universities' ranking position and quality scores. As long as higher-ranked universities provide favourable labour market outcomes to their graduates, universities and social planners should focus on and support the factors that affect institutions' academic reputation, such as research intensity and research-based teaching. The UK government should provide resources in order to promote institutional improvements across universities, enabling higher education to maximize its positive benefits to the community through higher employment rates and earned income. If universities with low reputations might negatively affect graduates' employment prospects, then social planners should intervene in order to set quality standards and boost universities' excellence. Graduates would then be judged more fairly by their own academic merit, rather than the reputation of their university.

In addition, as we have discussed, it seems that access to statistical information is vital for firms' screening strategies. Because in reality firms do not directly observe graduates' skills and motivation, free information from league tables on universities' performances might be used as a source in order to draw inferences about difficult-to-observe characteristics. By presenting a fair picture of their achievements and working on factors that affect academic quality, universities could strengthen their reputation in the market and improve their graduates' prospects.

Also, the outcome that better grades can positively affect applicants' access to vacancies and entry-level annual salaries, thus reducing the premium difference in labour market prospects between higher and lower-ranked universities, is of further importance for universities and students. Universities should create inclusive teaching and learning environments that allow students to receive inspiration, in order to engage more with their course and succeed in their studies. In the same time, for students it seems that the time and effort invested in order to secure a good grade is rewarded. Human capital and screening arguments then become important factors when evaluating the degree grade premiums.

Finally, we have to highlight that the results of this study are simply an indication of the relationship between the university attended and applicants' labour market outcomes. This study enabled us to examine differences in labour market prospects at the initial stage of a recruitment process, between students who have studied in different universities. As a result, the relation between university attended and graduates' actual performance has been 
not evaluated. Importantly also, whether better secondary schools may result in students' admission to better universities has not been evaluated. It is probable that attending a better primary and secondary school may result in improved labour market prospects. In this study, we did not have information regarding primary and secondary schools' quality scores in order to reveal potentially statistically significant patterns. In addition, the presented patterns are only applicable to the utilized applicants' profile, universities, job-search strategy, occupations, region and time period. Undoubtedly, further work is needed in order to provide further generalizations on the relations under examination.

\section{References}

Altonji, J. G. and Pierret, C. R. (2001). Employer Learning and Statistical Discrimination. Quarterly Journal of Economics, 116: 313-350.

Arcidiacono, P. Bayer, P. and Hizmo, A. (2010). Beyond Signaling and Human Capital: Education and the Revelation of Ability. American Economic Journal: Applied Economics, 2:76-104.

Bedard, K. (2001). Human Capital versus Signaling Models: University Access and High School Dropouts. Journal of Political Economy, 109: 749-775.

Drydakis, N. (2015). Economics Applicants in the UK Labour Market. International Journal of Manpower, 36: 296-333.

Black, D. A. and Smith, J. A. (2004). How Robust is the Evidence on the Effects of College Quality? Evidence from Matching. Journal of Econometrics, 121: 99-124.

Black, D. A. and Smith, J. A. (2006). Estimating the Returns to College Quality with Multiple Proxies for Quality. Journal of Labor Economics, 24: 701-728

Brewer, D. J. Eide, E. and Ehrenberg, R. (1999). Does it Pay to Attend an Elite Private College? Cross-Cohort Evidence on the Effects of College Type on Earnings. Journal of Human Resources, 34: 104-123.

Brewer, D. J. Gates, S. M. and Goldman, C.A. (2002). In Pursuit of Prestige: Strategy and Competition in US Higher Education. New Brunswick: Transaction Press.

Broecke, S. (2012). University Selectivity and Earnings: Evidence from UK Data on Applications and Admissions to University. Economics of Education Review, 31: 96107.

Chevalier, A. and Conlon, G. (2003) Does it Pay to Attend a Prestigious University? Centre for the Economics of Education (CEE) Discussion Paper P0033. 
Dale, S. B. and Krueger, A. B. (2002). Estimating the Payoff to Attending a More Selective College: An Application of Selection on Observables and Unobservable. The Quarterly Journal of Economics, 117: 1491-1527.

Dale, S. B. and Krueger, A. B. (2014). Estimating the Effects of College Characteristics over the Career Using Administrative Earnings Data. Journal of Human Resources, 49: 323-358.

Dobbs, R. L. Sun, J. Y. and Roberts, P. B. (2008). Human Capital and Screening Theories: Implications for Human Resource Development. Advances in Developing Human Resources, 10: 788-801.

Hartog, J. Sun, Y. and Ding, X. (2010). University Rank and Bachelor's Labour Market Positions in China. Economics of Education Review, 29: 971-979.

Hazelkorn, E. (2008). Learning to Live with League Tables and Ranking: The Experience of Institutional Leaders. Higher Education Policy, 21: 193-215.

Hanushek, E. A. and Kimko. D. D. (2000). Schooling, Labor Force Quality, and the Growth of Nations. American Economic Review, 90: 1184-1208.

Hanushek, E. and Welch, F. (2006). Handbook of Economics of Education. Amsterdam: Elsevier.

Higher Education Statistics Agency. (2013). Destination of Leavers from Higher Education: 2010/11. Cheltenham: Higher Education Statistics Agency.

Hoekstra, M. (2009). The Effect of Attending the Flagship State University on Earnings: A Discontinuity-Based Approach. The Review of Economics and Statistics, 91: 717-724.

Hussain. I. McNally, S. Shqiponja, T. (2009). University Quality and Graduate Wages in the UK. Institute for the Study of Labour IZA. Discussion Paper Series No. 4043. Bonn: Germany.

Geiger, R. L. (2004). Knowledge and Money, Research Universities and the Paradox of the Marketplace. Stanford: Stanford University Press.

Kjelland, J. (2008). Economic Returns to Higher Education: Signaling Versus Human Capital Theory; An Analysis of Competing Theories. The Park Place Economist, 16: 69-77.

Watts, D. (2003). Six Degrees: The Science of a Connected Age. New York: Norton, W.W. and Company. 
Table 1. Descriptive Statistics; Participants' Characteristics

\begin{tabular}{lll}
\hline Categories & Mean & \multicolumn{1}{l}{$\begin{array}{l}\text { Standard } \\
\text { Deviation }\end{array}$} \\
\hline Men (\%) & 47.16 & 0.42 \\
Age (continuous variable; years) & 21.15 & 0.57 \\
British-White (\%) & 71.03 & 0.62 \\
Married (\%) & 3.33 & 0.43 \\
Secondary education in State Schools (non fee-paying) (\%) & 87.16 & 0.38 \\
University grade obtained (continuous variable, out of 100) & 67.13 & 1.88 \\
Working experience (continuous variable; months) & 0.32 & 0.04 \\
Knowledge of software (Office, E-views, SPSS) (\%) & 87.86 & 0.16 \\
Pre-professional experience: projects delivery as part of major & 84.23 & 0.31 \\
modules (\%) & & \\
Pre-professional experience: quantitative methods used when & 83.53 & 0.26 \\
writing the final thesis (\%) & & \\
Percentage of applicants that include 'ability to work in team' in & 87.58 & 0.42 \\
their CV (\%) & & \\
Percentage of applicants that include 'communication skills' in & 85.05 & 0.39 \\
their CV (\%) & & \\
Percentage of applicants that include 'sociable' in their CV (\%) & 81.78 & 0.26 \\
Percentage of applicants that include 'amiable' in their CV (\%) & 72.32 & 0.19 \\
Percentage of applicants that include 'cinema as a hobby' in their & 74.69 & 0.26 \\
CV (\%) & & \\
Percentage of applicants that include 'music as a hobby' in their & 69.98 & 0.15 \\
CV (\%) & & \\
Contact details of two professors to stand as referees (\%) & 77.38 & 0.11 \\
\hline Observations & 64 & \\
\hline
\end{tabular}


Table 2. Descriptive Statistics; Jobs' and Firms' Characteristics

\begin{tabular}{lll}
\hline Categories & Mean & $\begin{array}{l}\text { Standard } \\
\text { Deviation }\end{array}$ \\
\hline Entry level annual salary (continuous variable) & $£ 31,110.2$ & $£ 5,324.6$ \\
Jobs in financial intermediation, consultancy and banking (\%) & 21.66 & 0.41 \\
Jobs in real estate and renting (\%) & 17.35 & 0.37 \\
Jobs in health industry and social support (\%) & 20.23 & 0.40 \\
Jobs in transport, storage and communication (\%) & 16.66 & 0.37 \\
Jobs in construction, manufacturing, electricity, gas and water & 24.08 & 0.43 \\
supply (\%) & & \\
Fixed contract vacancies (\%) & 22.14 & 0.41 \\
Multinational firm (\%) & 31.42 & 0.46 \\
Existence of human resources (\%) & 70.00 & 0.45 \\
Vacancies require online application (\%) & 40.71 & 0.49 \\
\hline Observations & 140 & \\
\hline
\end{tabular}


Table 3. Invitations to Interviews (Access to Vacancies) Outcomes

$\begin{array}{llllll}\text { Top 1 } & \text { Top 2 } & \text { Top 3 } & \text { Difference in treatment; } & \text { Difference in treatment; } \\ \text { University } & \text { University } & \text { University } & \text { Top1 University applicant } & \text { Top1 University applicant } \\ \text { applicant } & \text { applicant } & \text { applicant } & \text { vs } & \text { vs } \\ \text { invitations } & \text { invitations } & \text { invitations } & \text { Top 2 University applicant } & \text { Top 3 University applicant } \\ \text { to interviews } & \text { to interviews } & \text { to interviews } & & \end{array}$

to interviews to interviews to interviews

\begin{tabular}{lllll}
\hline $\begin{array}{l}\text { Panel I } \\
\text { Experiment 1 }\end{array}$ & $\begin{array}{l}59.4 \% \\
\mathrm{n}=69\end{array}$ & $\begin{array}{l}31.8 \% \\
\mathrm{n}=22\end{array}$ & $\begin{array}{l}21.7 \% \\
\mathrm{n}=15\end{array}$ & $\begin{array}{l}27.5 \text { percentage points } \\
\mathrm{n}=19 \\
x^{2}=9.7^{*}\end{array}$ \\
& & & \\
Panel II & & & \\
$\begin{array}{l}\text { Experiment 2 } \\
\mathrm{n}=71\end{array}$ & $\begin{array}{l}57.7 \% \\
\mathrm{n}=41\end{array}$ & $\begin{array}{l}40.8 \% \\
\mathrm{n}=29\end{array}$ & $\begin{array}{l}32.2 \% \\
\mathrm{n}=23\end{array}$ & $\begin{array}{l}16.9 \text { percentage points } \\
\mathrm{n}=12 \\
x^{2}=5.1 * *\end{array}$
\end{tabular}

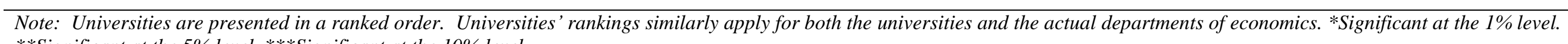
**Significant at the 5\% level. ***Significant at the $10 \%$ level. 
Table 4. Descriptive Statistics; Entry Level Annual Salaries

\begin{tabular}{|c|c|c|c|c|c|}
\hline & $\mathrm{I}$ & II & III & IV & $\mathrm{V}$ \\
\hline & $\begin{array}{l}\text { Entry level } \\
\text { annual } \\
\text { salary } \\
\text { (mean) }\end{array}$ & $\begin{array}{l}\text { Entry level } \\
\text { annual } \\
\text { salary } \\
\text { (standard } \\
\text { deviation) }\end{array}$ & $\begin{array}{l}\text { Difference in treatment; } \\
\text { Top1 University applicant } \\
\frac{\text { vs }}{\text { Top } 2 \text { University applicant }}\end{array}$ & $\begin{array}{l}\text { Difference in treatment; } \\
\text { Top1 University applicant } \\
\frac{\text { vs }}{\text { Top3 University applicant }}\end{array}$ & $\begin{array}{l}\text { Difference in treatment; } \\
\text { Top } 2 \text { University applicant } \\
\frac{\text { vs }}{\text { Top } 3 \text { University applicant }}\end{array}$ \\
\hline \multicolumn{6}{|l|}{$\begin{array}{l}\text { Panel I } \\
\text { Experiment } 1\end{array}$} \\
\hline Top 1 University applicant & $\begin{array}{l}£ 32,351.2 \\
n=41\end{array}$ & $£ 4,480.8$ & $\begin{array}{l}10.9 \text { percentage points } \\
\mathrm{t}=2.652 * *\end{array}$ & $\begin{array}{l}13.6 \text { percentage points } \\
\mathrm{t}=3.135^{*}\end{array}$ & $\begin{array}{l}4.1 \text { percentage points } \\
\mathrm{t}=0.738\end{array}$ \\
\hline Top 2 University applicant & $\begin{array}{l}£ 29,145.4 \\
n=22\end{array}$ & $£ 4,744.0$ & & & \\
\hline Top 3 University applicant & $\begin{array}{l}£ 27,926.6 \\
n=15\end{array}$ & $£ 5,263.4$ & & & \\
\hline \multicolumn{6}{|l|}{$\begin{array}{l}\text { Panel II } \\
\text { Experiment } 2\end{array}$} \\
\hline Top 1 University applicant & $\begin{array}{l}£ 31,832.4 \\
n=41\end{array}$ & $£ 5,545.1$ & $\begin{array}{l}6.8 \text { percentage points } \\
\mathrm{t}=1.674 * * *\end{array}$ & $\begin{array}{l}9.2 \text { percentage points } \\
\mathrm{t}=2.066 * *\end{array}$ & $\begin{array}{l}2.6 \text { percentage points } \\
\mathrm{t}=0.538\end{array}$ \\
\hline Top 2 University applicant & $\begin{array}{l}£ 29,662.0 \\
n=29\end{array}$ & $£ 5,038.7$ & & & \\
\hline Top 3 University applicant & $\begin{array}{l}£ 28,882.6 \\
n=23\end{array}$ & $£ 5,360.9$ & & & \\
\hline
\end{tabular}

Notes: Universities are presented in a ranked order. Universities' rankings similarly apply for both the universities and the actual departments of economics. *Significant at the 1\% level. **Significant at the $5 \%$ level. ***Significant at the $10 \%$ level. 
Table 5. Estimations: Invitations to Interviews and Entry-level Annual Salaries

$\begin{array}{llll}\text { Model I: } & \text { Model II: } & \text { Model III: } & \text { Model IV: } \\ \text { Invitations to } & \text { Invitations to } & \text { Entry-level } & \text { Entry-level } \\ \text { interviews } & \text { interviews } & \text { annual } & \text { annual } \\ \text { Probit } & \text { Probit } & \text { salaries OLS } & \text { salaries OLS } \\ \text { estimations } & \text { estimations } & \text { estimations } & \text { estimations }\end{array}$

$\begin{array}{llll}\text { Experiment } 1 & \text { Experiment } 2 & \text { Experiment } 1 & \text { Experiment } 2\end{array}$

Top 2 University applicant

Top 3 University applicant

Sending order

On-line application

Multinational firm

Human resources

Fixed contract

Financial intermediation, consultancy and banking

Real estate and renting

Health industry and social

support

Transport, storage and communication

University grade obtained

Log Likelihood

Wald $\mathrm{Chi}^{2}$

Prob $>\mathrm{Chi}^{2}$

Pseudo $\mathrm{R}^{2}$

Observations
$-0.279(0.072)^{*}$

$-0.394(0.063)^{*}$

$0.056(0.076)$

$-0.035(0.080)$

$0.143(0.088)$

$0.251(0.076)^{*}$

$-0.001(0.107)$

$0.455(0.103)^{*}$

$0.430(0.112)^{*}$

$0.222(0.113)^{* * * *}$

$0.081(0.118)$

$-103.273$

46.13

0.000

0.246

207
$-0.173(0.084)^{* *}$

$-0.285(0.076)^{*}$

$0.082(0.078)$

$0.094(0.079)$

$0.191(0.089)^{* *}$

$0.350(0.081)^{*}$

$0.036(0.095)$

$0.243(0.102)^{*}$

$-0.113(0.048)^{* *}$

$-0.153(0.044)^{*}$

$0.036(0.044)$

$-0.031(0.042)$

$0.040(0.043)$

$0.053(0.064)$

$-0.066(0.069)$

0.013(0.047)

$0.121(0.106)$

0.095 (0.116)

$0.036(0.058)$

$-0.116(0.064)^{* * *}$

$-0.000(0.108)$

$-0.028(0.065)$

$0.060(0.073)$

$0.043(0.012)^{*} \quad-$

$-120.281$

42.35

0.152

3.41

$0.028(0.015)^{* *}$

0.000

0.000

0.185

0.286

78
0.183

1.99

0.039

$-0.042(0.047)$

$-0.081(0.043)^{* *}$

$-0.044(0.046)$

$-0.035(0.042)$

$0.026(0.040)$

$0.106(0.054)^{* * *}$

$-0.010(0.049)$

$0.023(0.078)$

$0.034(0.078)$

$0.023(0.068)$

0.168

93

Notes: Universities are presented in a ranked order. Universities' rankings similarly apply for both the universities and the actual departments of economics. Robust standard errors are reported clustered at the occupation level. *Significant at the 1\% level. **Significant at the 5\% level. ***Significant at the $10 \%$ level. 
Model I:

Invitations to interviews

Probit estimations

Experiment 1

and

Experiment 2
Model II:

Entry-level annual salaries

OLS estimations

Experiment 1

and

Experiment 2
Top 2 University applicant

Top 3 University applicant

Experiment 2

Top 2 University applicant $x$ Experiment 2

Top 3 University applicant $x$ Experiment 2

Sending order

On-line application

Multinational firm

Human resources

Fixed contract

Financial intermediation, consultancy and banking

Real estate and renting

Health industry and social support

Transport, storage and communication

University grade obtained

Log Likelihood

Wald $\mathrm{Chi}^{2}$

Prob $>\mathrm{Chi}^{2}$

Pseudo R ${ }^{2}$

Observations

$-0.208(0.056)^{*}$
$-0.318(0.045)^{*}$
$-0.033(0.020)$
$0.065(0.027)^{*}$
$0.094(0.038)^{*}$
$0.059(0.046)$
$0.016(0.025)$
$0.153(0.125)$
$0.274(0.053)$
$0.021(0.083)$
$0.372(0.073)^{*}$
$0.216(0.093)^{*}$
$0.163(0.089)^{* * *}$
$0.063(0.196)$
$0.022(0.004)^{*}$
-126.036
46.83
0.000
0.263
420

$-0.081(0.016) *$

$-0.095(0.021)^{*}$

$-0.009(0.006)$

$0.027(0.014)^{* * *}$

$0.029(0.016)^{* * *}$

$0.024(0.018)$

$-0.032(0.038)$

$0.037(0.028)$

$0.047(0.025)^{* * *}$

$-0.042(0.037)$

$0.022(0.042)$

$0.031(0.047)$

$-0.054(0.029)^{* * *}$

$0.025(0.044)$

$0.018(0.010)^{* *}$

0.165

3.64

0.000

0.292

171

Notes: Universities are presented in a ranked order. Universities' rankings similarly apply for both the universities and the actual departments of economics. Robust standard errors are reported clustered at the occupation level. *Significant at the 1\% level. **Significant at the $5 \%$ level. ***Significant at the $10 \%$ level. 
Table 7. Generalized Method of Moment Estimations: Invitations to Interviews and Entry-level Annual Salaries

$\begin{array}{llll}\text { Model I: } & \text { Model II: } & \text { Model III: } & \text { Model IV: } \\ \text { Invitations to } & \text { Invitations to } & \text { Entry-level } & \text { Entry-level } \\ \text { interviews } & \text { interviews } & \text { annual salaries } & \text { annual salaries } \\ \text { Probit estimations } & \text { Probit estimations } & \text { OLS estimations } & \text { OLS estimations }\end{array}$

$\begin{array}{llll}\text { Experiment } 1 & \text { Experiment } 2 & \text { Experiment } 1 & \text { Experiment } 2\end{array}$

\section{Specification I}

Top 2 University applicant

Top 3 University applicant

$-0.242(0.042)^{*}$

$-0.156(0.051)^{*}$

$-0.084(0.037)^{*}$

$-0.038(0.044)$

$-0.333(0.047)^{*}$

$-0.221(0.062)^{*}$

$-0.127(0.051)^{*}$

$-0.055(0.028)^{* * *}$

Russell Group Membership

$0.282(0.065)^{*}$

$0.198(0.071)^{*}$

$0.113(0.040)^{*}$

$0.064(0.034) * *$

\begin{tabular}{|c|c|c|c|c|}
\hline \multicolumn{5}{|l|}{ Specification II } \\
\hline Top 2 University applicant & $-0.246(0.046)^{*}$ & $-0.160(0.052)^{*}$ & $-0.091(0.037)^{*}$ & $-0.038(0.045)$ \\
\hline Top 3 University applicant & $-0.341(0.048)^{*}$ & $-0.238(0.061)^{*}$ & $-0.129(0.053)^{*}$ & $-0.059(0.032) * *$ \\
\hline Research Assessment Exercise & $0.021(0.006)^{*}$ & $0.014(0.007)^{*}$ & $0.029(0.003)^{*}$ & $0.017(0.006)^{*}$ \\
\hline $\begin{array}{l}\text { Research Assessment Exercise x } \\
\text { Top } 2 \text { University applicant }\end{array}$ & $-0.014(0.000)^{*}$ & $-0.013(0.000)^{*}$ & $-0.010(0.004)^{*}$ & $-0.011(0.004)^{*}$ \\
\hline $\begin{array}{l}\text { Research Assessment Exercise x } \\
\text { Top } 3 \text { University applicant }\end{array}$ & $-0.025(0.004) *$ & $-0.015(0.006)^{*}$ & $-0.026(0.009)^{*}$ & $-0.020(0.008)^{*}$ \\
\hline \multicolumn{5}{|l|}{ Specification III } \\
\hline Top 2 University applicant & $-0.271(0.048)^{*}$ & $-0.158(0.081)^{* *}$ & $-0.109(0.053)^{* *}$ & $-0.039(0.045)$ \\
\hline Top 3 University applicant & $-0.336(0.060)^{*}$ & $-0.217(0.059)^{*}$ & $-0.135(0.053)^{*}$ & $-0.076(0.041) * *$ \\
\hline National Student Survey & $-0.013(0.010)$ & $-0.023(0.019)$ & $-0.007(0.012)$ & $-0.011(0.012)$ \\
\hline National Student Survey x & $-0.032(0.027)$ & $-0.038(0.034)$ & $0.052(0.039)$ & $0.039(0.031)$ \\
\hline Top 2 University applicant & & & & \\
\hline National Student Survey x & $0.029(0.021)$ & $0.031(0.033)$ & $0.036(0.028)$ & $0.041(0.035)$ \\
\hline Top 3 University applicant & & & & \\
\hline
\end{tabular}

Specification II

Top 2 University applicant

$-0.246(0.046) *$

$-0.160(0.052)^{*}$

$-0.091(0.037)^{*}$

$-0.341(0.048)^{*}$

$-0.059(0.032)$

$0.021(0.006)$

$0.014(0.007)$

$0.029(0.003)^{*}$

$0.017(0.006)^{*}$

Research Assessment Exercise $x$

$-0.025(0.004)^{*}$

$-0.015(0.006)^{*}$

$-0.026(0.009)^{*}$

$-0.020(0.008)^{*}$ 
Appendix I. UK Universities: Key Word Definitions

$\begin{array}{ll}\text { University entry standards } & \text { UK universities set entry requirements, which typically involve } \\ \text { qualifying grades (A-levels). Students decide which set of } \\ \text { universities to apply to for admission, and universities independently } \\ \text { decide whether to admit or reject the students. Universities' entry } \\ \text { standards act as a guide for students. Students know that they are } \\ \text { unlikely to receive an offer from a university with higher } \\ \text { standardized grade levels than they have obtained. Students apply to } \\ \text { universities that they believe will accept them for admission based on } \\ \text { the grade levels they have earned. The students decide then which } \\ \text { university they will attend from the range of universities that will } \\ \text { admit them. }\end{array}$

League Tables

Three national rankings of universities in the United Kingdom are published annually, by The Complete University Guide, The Guardian, and jointly by The Times and The Sunday Times. The league tables are considered to be a type of organizational report card that provides explicit organizational rankings based on the universities' entry standards, the scientific achievements realized at the university, and their students' satisfaction evaluations.

Research Assessment Exercise (RAE)

The RAE is undertaken approximately every six years by the four UK higher education funding councils, in order to evaluate the quality of research undertaken by the British higher education institutions. These rankings are used to inform the allocation of quality-weighted research funding that each higher education institution receives from their national council.

National Student Survey (NSS)

The NSS is a survey of all final-year degree students. The survey is designed to assess students' opinions of the quality of their degree programmes with seven different scores, including an overall satisfaction mark.

Russell Group Membership

The Russell Group represents universities that describe themselves as institutions that are committed to maintaining the very best research, an outstanding teaching and learning experience, and unrivalled links with business and the public sector. Russell Group universities are the most highly-ranked institutions, based on all UK league tables. Russell Group universities have the highest research outcomes, as measured by the Research Assessment Exercise score (RAE), and the most satisfied students, as measured by the National Student Survey score (NSS). 


\section{Appendix II. Universities' Characteristics}

Top 1 University^^

Entry standards for the subdiscipline BSc in economics

Russell Group

Research outcomes score (RAE)

Students' Satisfaction Score (NSS)

\author{
$\mathrm{AAB}$, including $\mathrm{A}$ in \\ mathematics
}

Yes

Higher RAE score compared to Top 2 and Top 3

Lower NSS score compared to Top 2 and Top 3
Top 2 University^^

$\mathrm{AAB}$, including $\mathrm{A}$ in mathematics
$\mathrm{AAB}$, including $\mathrm{A}$ in mathematics

Top 3 University^^^

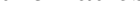

\footnotetext{
Notes: Universities are presented in a ranked order. Universities' rankings similarly apply for both the universities and the actual departments of economics. ${ }^{\wedge}$ Ranked in the first ten based on the league tables. ${ }^{\wedge}$ Ranked in the second ten based on the league tables. $\wedge^{\wedge \wedge}$ Ranked in the third ten based on the league tables. The RAE and NSS comparisons similarly apply for both the universities and the actual department of economics.
}

Lower RAE score compared to

Top 1 and Top 2

Higher NSS score $\begin{array}{ll}\text { compared to } & \text { compared to } \\ \text { Top } 1 \text { and lower NSS score } & \text { Top } 1 \text { and Top 2 }\end{array}$ compared to Top 3 
Appendix III. Experiment 1; Matched Pairs

Top 1 University applicant ${ }^{\wedge}$

Demographic characteristics

21 years old lady

White-British

Unmarried

Studied in state primary and secondary schools

Pre-university qualifications

$\mathrm{A}$ in Mathematics at A-level

$\mathrm{A}$ in Economics at A-level

B in Statistics at A-level

University qualifications

$3^{\text {rd }}$ year BSc undergraduate student

in Economics

Grade obtained: 64\% (upper-

second)

Quantitative skills

No work experience

Academic referees (contact details

of two professors were provided)

$\underline{\text { Skills }}$

Ability to work in teams and to communicate well with others

Personal characteristics

Sociable and amiable

Spare time interests

Cinema, music
Top 2 University applicant ${ }^{\wedge} \wedge$

Demographic characteristics

21 years old lady

White-British

Unmarried

Studied in state primary and

secondary schools

Pre-university qualifications

A in Mathematics at A-level

$\mathrm{A}$ in Economics at A-level

$\mathrm{B}$ in Statistics at A-level

University qualifications

$3^{\text {rd }}$ year BSc undergraduate student

in Economics

Grade obtained: $64 \%$ (upper-

second)

Quantitative skills

No work experience

Academic referees (contact details

of two professors were provided)

$\underline{\text { Skills }}$

Ability to work in teams and to communicate well with others

Personal characteristics

Sociable and amiable

Spare time interests

Cinema, music
Top 3 University applicant ^^^

Demographic characteristics

21 years old lady

White-British

Unmarried

Studied in state primary and secondary schools

Pre-university qualifications

$\mathrm{A}$ in Mathematics at A-level

$\mathrm{A}$ in Economics at A-level

B in Statistics at A-level

University qualifications

$3^{\text {rd }}$ year BSc undergraduate student

in Economics

Grade obtained: 64\% (upper-

second)

Quantitative skills

No work experience

Academic referees (contact details of two professors were provided)

Skills

Ability to work in teams and to communicate well with others

Personal characteristics

Sociable and amiable

Spare time interests

Cinema, music

Notes: Universities are presented in a ranked order. Universities' rankings similarly apply for both the universities and the actual departments of economics. ${ }^{\wedge}$ Ranked in the first ten based on the league tables. ${ }^{\wedge}$ Ranked in the second ten based on the league tables. ${ }^{\wedge \wedge}$ Ranked in the third ten based on the league tables. 


\section{Appendix IV. Experiment 2; Matched Pairs}

Top 1 University applicant ${ }^{\wedge}$

Demographic characteristics

21 years old lady

White-British

Unmarried

Studied in state primary and secondary schools

Pre-university qualifications

$\mathrm{A}$ in Mathematics at A-level

$\mathrm{A}$ in Economics at A-level

$\mathrm{B}$ in Statistics at A-level

University qualifications

$3^{\text {rd }}$ year BSc undergraduate student

in Economics

Grade obtained: 58\% (lower-

second)

Quantitative skills

No work experience

Academic referees (contact details of two professors were provided)

Skills

Ability to work in teams and to communicate well with others

Personal characteristics

Sociable and amiable

Spare time interests

Cinema, music
Top 2 University applicant ${ }^{\wedge}$

Demographic characteristics

21 years old lady

White-British

Unmarried

Studied in state primary and secondary schools

Pre-university qualifications

A in Mathematics at A-level

$\mathrm{A}$ in Economics at A-level

$B$ in Statistics at A-level

University qualifications

$3^{\text {rd }}$ year BSc undergraduate student

in Economics

Grade obtained: 68\% (upper-

second)

Quantitative skills

No work experience

Academic referees (contact details

of two professors were provided)

$\underline{\text { Skills }}$

Ability to work in teams and to communicate well with others

Personal characteristics

Sociable and amiable

Spare time interests

Cinema, music
Top 3 University applicant ${ }^{\wedge \wedge \wedge}$

Demographic characteristics

21 years old lady

White-British

Unmarried

Studied in state primary and

secondary schools

Pre-university qualifications

$\mathrm{A}$ in Mathematics at A-level

$\mathrm{A}$ in Economics at A-level

$\mathrm{B}$ in Statistics at A-level

University qualifications

$3^{\text {rd }}$ year BSc undergraduate student

in Economics

Grade obtained: $75 \%$ (first)

Quantitative skills

No work experience

Academic referees (contact details

of two professors were provided)

Skills

Ability to work in teams and to communicate well with others

Personal characteristics

Sociable and amiable

Spare time interests

Cinema, music

Notes: $\wedge^{\wedge}$ Ranked in the first ten based on the league tables. ${ }^{\wedge}$ Ranked in the second ten based on the league tables. ${ }^{\wedge \wedge}$ Ranked in the third ten based on the league tables. Universities' rankings similarly apply for both the universities and the actual departments of economics. 


\section{Appendix V. Cover Letter and Curriculum Vitae}

\section{Cover Letter}

April/May 2014

Dear Sir/Madam,

Please find attached my Curriculum Vitae for your kind consideration for the vacancy as was advertised in.... I am 21 years old and in July, I will be awarded a BSc in Economics from the University of ... I am very interested for the advertised job, and I would appreciate the opportunity to speak with you in person to further discuss my qualifications, your business objectives, and the talents I can bring to your organization. During my studies, I acquired strong academic skills, and I have ability to work in teams and to communicate well with others. The job you are offering matches both my personal and professional interests.

I look forward to hearing from you soon. In the meantime, please do not hesitate to contact me if you require further information.

Yours sincerely,

Name and surname

\section{Curriculum Vitae}

First Name:

Last Name:

Sex: Female

Ethnicity: White-British

Marital Status: Unmarried

Date of Birth: .../.../1991

Current Address: Location (university's city)

Telephone: Mobile

E-mail: University e-mail

Higher education

Level and subject of degree: BSc in Economics, University of ...

Grade obtained:

Main courses of study: Microeconomics, Macroeconomics and Econometrics

Duration of studies: 2011-2014 (3 year programme)

High school education (State Schools; non fee-paying)

Names and addresses

Period of study and A-levels:

A in Mathematics at A-level

A in Economics at A-level

A in Statistics at B-level

Knowledge of software

Microsoft Office, E-Views, and SPSS

Pre-professional experience

Practical experiences gained by delivering projects as a part of major modules (microeconomics, macroeconomics, and econometrics).

Skills: Ability to work in teams and to communicate well with others.

Personal characteristics: Sociable and amiable.

Spare time interests: Cinema, music

Academic referees (contact details for two professors were provided) 


\section{Appendix VI.}

Variables Coding

\begin{tabular}{|c|c|}
\hline Name & Definition \\
\hline \multicolumn{2}{|l|}{ I. Dependent variables } \\
\hline $\begin{array}{l}\text { Call for interview (access to } \\
\text { vacancies) }\end{array}$ & 1 if the applicant receives an invitation for interview; 0 otherwise \\
\hline Entry-level annual salary & Natural log of the entry-level annual salary before taxes (continuous variable) \\
\hline II. Entry standards & $\mathrm{AAB}$, including $\mathrm{A}$ in mathematics (for the sub-discipline: $\mathrm{BSc}$ in economics) \\
\hline \multicolumn{2}{|l|}{ III. University dummies } \\
\hline Top 1 & Reference category \\
\hline Top 2 & 1 if the university is ranked second in this sample based on the league tables; 0 otherwise \\
\hline Top 3 & 1 if the university is ranked third in this sample based on the league tables; 0 otherwise \\
\hline \multicolumn{2}{|l|}{ IV. Reputation Index } \\
\hline Russell Group membership & 1 if the university is a Russell Group member; 0 otherwise \\
\hline $\begin{array}{l}\text { Research Assessment Exercise } \\
\text { (RAE) }\end{array}$ & $\begin{array}{l}\text { Research Assessment Exercise score (for the sub-discipline: BSc in economics) (continuous } \\
\text { variable) }\end{array}$ \\
\hline National Student Survey & $\begin{array}{l}\text { National Student Survey score (for the sub-discipline: BSc in economics) (continuous } \\
\text { variable) }\end{array}$ \\
\hline \multicolumn{2}{|l|}{ V. Applicant's characteristics } \\
\hline Male & 1 if the applicant is male; 0 otherwise \\
\hline Age & Years of age (continuous variable) \\
\hline British-White & 1 if the applicant is British-White; 0 otherwise \\
\hline Married & 1 if the applicant is married; 0 otherwise \\
\hline Grade obtained & Grade (continuous variable) \\
\hline Working experience & Months of working experience (continuous variable) \\
\hline Knowledge of software & $\begin{array}{l}1 \text { if the applicant has knowledge of software (Microsoft Office, E-views, and SPSS); } 0 \\
\text { otherwise }\end{array}$ \\
\hline Skills: Ability to work in teams & 1 if the applicant includes 'ability to work in teams' in her/his CV; 0 otherwise \\
\hline Skills: Communication skills & 1 if the applicant includes 'communication skills' in her/his CV; 0 otherwise \\
\hline \multicolumn{2}{|l|}{ Pre-professional experience: } \\
\hline $\begin{array}{l}\text { Projects delivery as part of major } \\
\text { modules }\end{array}$ & $\begin{array}{l}1 \text { if the applicant delivered projects as part of her/his major modules (microeconomics, } \\
\text { macroeconomics, econometrics); } 0 \text { otherwise }\end{array}$ \\
\hline \multicolumn{2}{|l|}{ Pre-professional experience: } \\
\hline $\begin{array}{l}\text { Quantitative methods used when } \\
\text { writing the thesis }\end{array}$ & 1 if the applicant used econometrics when writing her/his thesis; 0 otherwise \\
\hline Personality: sociable & 1 if the applicant includes 'sociable' in her/his CV; 0 otherwise \\
\hline Personality: amiable & 1 if the applicant includes 'amiable' in her/his $\mathrm{CV}$; 0 otherwise \\
\hline Spare time interest: cinema & 1 if the applicant includes 'cinema as a hobby' in her/his CV; 0 otherwise \\
\hline Spare time interest: music & 1 if the applicant includes 'music as a hobby' in her/his CV; 0 otherwise \\
\hline Letters of references & 1 if the applicant provides contact details of at least two professors; 0 otherwise \\
\hline Applicant location & Applicant location is university region \\
\hline \multicolumn{2}{|l|}{ VI. Occupations } \\
\hline $\begin{array}{l}\text { Financial intermediation, } \\
\text { consultancy and banking }\end{array}$ & 1 if the job opening is for financial intermediation, consultancy and banking; 0 otherwise \\
\hline Real estate and renting & 1 if the job opening is for real estate and renting; 0 otherwise \\
\hline Health industry and social support & 1 if the job opening is for the health industry and social support; 0 otherwise \\
\hline $\begin{array}{l}\text { Transport, storage and } \\
\text { communication }\end{array}$ & 1 if the job opening is for transport, storage and communication; 0 otherwise \\
\hline $\begin{array}{l}\text { Construction, manufacturing, } \\
\text { electricity, gas and water supply }\end{array}$ & Reference category \\
\hline \multicolumn{2}{|l|}{ VII. Job and firm characteristics } \\
\hline Fixed-term contract & 1 if the vacancy is on a fixed-term contract; 0 otherwise \\
\hline Multinational firm & 1 if the firm is multinational; 0 otherwise \\
\hline Human resources & 1 if the firm has a human resources department; 0 otherwise \\
\hline \multicolumn{2}{|l|}{ VIII. Study's controls } \\
\hline Sending order & 1 if the application from Top 1 University applicant was sent first, 0 otherwise \\
\hline Online application & 1 if the firm requires an online job application; 0 otherwise \\
\hline
\end{tabular}

